i stamtąd zostały zaczerpnięte komentarze umieszczone w przypisach. Zupełnie natomiast brakuje uwag odnoszących się do terminów niejasnych (może

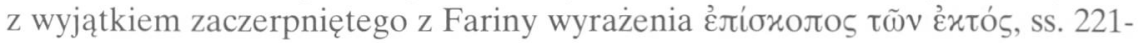
222), tak jakby T. Wnętrzak w ogóle nie zmagała się z tym trudnym tekstem). Dopiero to pozwala dostrzec jedyną przewagę (jeśli można użyć takiego słowa) edycji Migne'a nad wydaniami Heikela i Winkelmanna - jedynie ona jest bilingwiczna i poza tekstem greckim podaje przekład łaciński. Oczywiście, zarówno na podstawie tak krótkiego fragmentu, jak i faktu, że przekład nie musi dosłownie być wierny oryginałowi, żeby dobrze oddawał jego sens, nie pozwalają pewnie twierdzić, że podstawą tłumaczenia był tekst łaciński; wszelako uzasadnione wątpliwości pozostają (a po lekturze wprowadzenia, ewentualny wybór tekstu łacińskiego wcale nie musi dziwić). Być może jest to przekład z greki, przy czym fragmenty oddane są z tłumaczenia łacińskiego lub odwrotnie, tekst grecki mógł być tylko tekstem pomocniczym - Autorka korzystała niewątpliwie z oryginału, choć nie wiadomo, w jak dużym zakresie, np. w VC IV 59 „liczne mieszkania” to raczej łacińskie plurima habitacula, niż

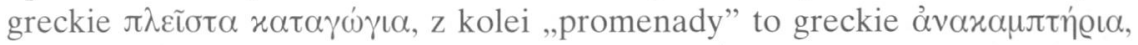
w znaczeniu podanym przez słownik Lampego (jest ono, co prawda, dysku-

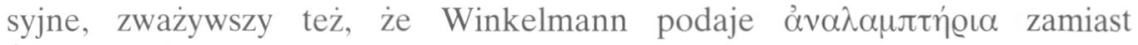

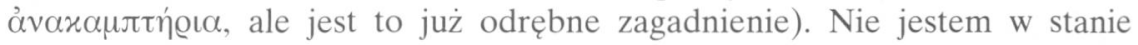
w tym momencie udzielić jednoznacznej odpowiedzi na postawione przeze mnie pytanie, ale kieruję je do Tłumaczki, Wydawcy (jeśli zechcą odpowiedzieć na nie) i do Czytelników.

Paweł Wróblewski - Warszawa, UW

\title{
Beata PAWŁOWSKA, Urbs sacra. Pielgrzymki chrześcijańskie i podróże religijne do Rzymu w starożytności chrześcijańskiej (IV-VII wiek), Kraków 2007, Wydawnictwo WAM, ss. 372 + XLVIII
}

Książka B. Pawłowskiej jest ważną pozycją, dotyczącą chrześcijańskich pielgrzymek późno antycznych, z uwagi na to, że literatura polska na ten temat jest uboga (z ważniejszych opracowań należy wymienić artykuł E. Wipszyckiej z 1993 r. - Pielgrzymki starożytne: problem definicji i cezur, w: Peregrinationes. Pielgrzymki w kulturze dawnej Europy, red. H. Manikowska - H. Zaremska, Warszawa 1995, 17-28; oraz wybór fragmentów Itinerariów w przekładzie, z wstępem i komentarzem P. Iwaszkiewicza - Do Ziemi Świętej, przedmowa M. Starowieyski, OŻ XIII, Kraków 1996) i koncentruje się na wschodniej części Cesarstwa Rzymskiego (choćby oba wspomniane opracowania), natomiast Urbs sacra jest pierwszą tak obszerną publikacją w języku polskim, dotyczącą pielgrzymek w łacińskojęzycznej części Imperium Romanum. 
Książka składa się z siedmiu rozdziałów: I. „Perigrnationes w starożytności chrześcijańskiej - problem definicji” (ss. 27-37), II. „Peregrynacje w świecie starożytnym” (ss. 39-76), III. „Geneza chrześcijańskich peregrynacji” (ss. 7791), IV. „Szlaki prowadzące do Rzymu” (ss. 93-101), V. „Urbs sacra - główne miejsca kultu w IV-VII wieku)” (ss. 103-214), VI. „Organizacja rzymskich peregrinationes” (ss. 215-264), VII. „Peregrini w Rzymie” (ss. 265-316). Natomiast zasadniczo publikację można podzielić na dwie części: wprowadzającą (rozdziały I-III) i właściwą (rozdziały IV-VII). Opracowanie zawiera ponadto tabele, ilustracje oraz bogatą bibliografię (szkoda, że nie do końca pokrywającą się z literaturą cytowaną w przypisach).

Część pierwsza jest ogólnym omówieniem problematyki pielgrzymek wczesnochrześcijańskich. Autorka nakreśla w niej bardzo szerokie tło pielgrzymek do Rzymu, i mimo podtytułowej „starożytności chrześcijańskiej”, uwzględnia pielgrzymki chrześcijańskie w kontekście nie tylko późnoantycznych, lecz w ogóle starożytnych podroży religijnych w basenie Morza Śródziemnego (w religiach grecko-rzymskich i w judaizmie). B. Pawłowska słusznie odróżnia pielgrzymkę od podróży religijnej, pisząc, że ,istnieje metodyczna potrzeba rozróżnienia pomiędzy ludźmi odwiedzającymi pobliskie sanktuarium (...), a przybyłymi pielgrzymami sensu stricto” (ss. 20 i 29) i dodając: „Wydaje się, że błędem jest nazywanie terminem "pielgrzymi», dosłownie wszystkich przybyłych ad loca sancta, niezależnie od wszelkich towarzyszących im okoliczności" (s. 37). $\mathrm{Z}$ drugiej strony Autorka twierdzi, że ,w niektórych przypadkach granica między nimi [obiema wymienionymi grupami] jest bardzo subtelna $\mathrm{i}$ w gruncie rzeczy nikła”, a „religijne intencje przyświecające pegrinationes tym długim i tym krótszym były podobne". Czy należy zatem wyróżniać kategorie osób przybywających do sanktuariów? Po pierwsze, mimo podobnych intencji towarzyszących przybyszom z bliska i z daleka, trudno nie zgodzić się z E. Wipszycką, że długa podróż (pamiętamy, że np. podróż pielgrzyma z Bordeaux, opisana w Itinerarium Burdigalense - więc na trasie Bordeaux - Jerozolima - Mediolan, trwała około roku) miała zupełne inny wymiar niż np. jednodniowy marsz do pobliskiego sanktuarium świętego (poza tym, np. Egeria odbywała długą i kosztowna podróż jako reprezentantka bliżej nieznanego nam kręgu osób, którym relacjonowała swoją pielgrzymkę, i z którymi przygotowywała się do niej przed podróżą, choćby studiując Pismo Święte) i dokonanie takiego rozróżnienia jest rzeczywiście istotne. B. Pawłowska nie wyjaśnia, na czym polega owa „metodyczna potrzeba" owego zróżnicowania. Otóż, zależy ona od tego, jakie aspekty pielgrzymek chcemy badać. Jeśli np. chodzi o ustalenie samego faktu kultu pewnego męczennika nie ma wielkiego znaczenia, skąd przybywali pielgrzymi do jego grobu; ale jeśli np. na podstawie wielkości kościoła dążymy do określenia liczby osób przybywających z daleka (bo o takich podróżach informują nas źródła), wtedy sugerowanie się liczbą ogółu nawiedzających sanktuarium może być zwodnicze (podobnie jak w przypadku ksenodochiów, gdzie zatrzymywać 
mógł się każdy, kto mieszkał dalej od sanktuarium niż pół dnia czy dzień drogi, a nie tylko przybysze z odległych stron).

Następnie Autorka omawia peregrinationes w świecie grecko-rzymskim (skupia się na Asklepionach - niestety zabrakło odniesień do chrześcijańskich elementów pielgrzymowania i kultów świętych nawiązujących do Asklepinów, np. św. Demetriusz uzdrawiał we śnie wiernych, którzy spędzali noc w bazylice w Tesalonikach) i w tradycji judaistycznej i wreszcie podróże chrześcijan do Ziemi Świętej. W ostatnim podrozdziale (Peregriantio Christiana) występuje jednak kilka nieścisłości. Po pierwsze, Autorka twierdzi, że pielgrzymki podejmowano m.in „dla zadośćuczynienia za grzechy” (s. 70, por. też s. 32), nie powołując się przy tym na konkretne źródła. A szkoda, ponieważ w pierwszych Itinerariach i tekstach dotyczących pielgrzymek nie odnajdujemy takiego motywu wyruszania w drogę, co zresztą może wydawać się dziwne z dzisiejszego punktu widzenia; pierwszą taką pielgrzymką mogła być podróż Heleny do Palestyny, jeśli przyjmiemy, że matka Konstantyna miała jakiś udział w śmierci Fausty, ale z Vita Consantini (III 42) wynika, że raczej była to oficjalna wizyta. Po drugie, opisując budowę Bazyliki Grobu Bożego B. Pawłowska pisze (s. 69): „, 325 r. Matka Konstantyna - Helena, «która otrzymała we śnie szereg proroczych widzeń w rezultacie udała się do Jerozolimy» (cytat z Sokratesa HE I 17, 1, odnotowany w przypisie). Jeśli wierzyć późniejszej, przekazanej w Historii Sokratesa legendzie, to jej dziełem było odnalezienie relikwii Krzyża Chrystusowego. Za jej sprawą wzniesiono na miejscu Grobu Świętego w 335 r. wspaniałą bazylikę". W przypisie Autorka podaje odpowiedni cytat z HE Sokratesa i odsyła do książki H.J. Drijversa - Helena Augusta: the mother of Constantine the Great and the Legend of her finding of the true Cross, Leiden 1992 (z którą, jak się wydaje, zapoznała się dość pobieżnie). Problem w tym, że H.J. Drijvers przyjmuje datowanie pielgrzymki Heleny za E.D. Huntem (którego książkę Holy Land pilgrimage in the later Roman Empire $A D$ 312-460, Oxford 1982, Autorka cytuje też w kilku innych miejscach), a żaden z tych autorów nie opowiada się za rokiem 325, tylko 326 (Hunt) i 327 (Drijvers, co podtrzymał w późniejszych publikacjach). Na dodatek książka Drijversa to próba odróżnienia Heleny historycznej od Heleny legendarnej, a autor odrzuca możliwość udziału Heleny w odnalezieniu drzewa krzyża, czy też tego co za nie uznano. Paradoksalnie, tezy przedstawionej przez B. Pawłowską broni S. Borgehammar, oponent Drijversa, który w książce How the Holy Cross was found. From Event to Medieval Legend (Stockholm 1991) dowodzi prawdziwości historii opisanej w legendzie o Helenie i odnalezieniu krzyża (przy czym książka stwarza bardziej wrażenie polemiki z Drijversem wcześniejszą duńską wersją, Helena Augusta, wydaną w Groningen w 1989 r. pod tytułem Helena Augusta: waarheid en legende - niż dążenia do prawdy historycznej). Wreszcie Helena nie była inicjatorką wzniesienia Bazylik Grobu Bożego: przybyła do Palestyny, kiedy budowa była już rozpoczęta (por. 
P. Wróblewski, Helena Augusta i lignum Crucis - historia czy legenda?, „Almanach Historyczny" t. 10 - w druku). Podobnie, z pobieżną lekturą mamy do czynienia w przypadku Vita Constantini $(=\mathrm{VC})$ Euzebiusza z Cezarei. Autorka pisząc o liście Konstantyna do Makarego w sprawie budowy kościoła w Mamre (s. 71), odwołuje się do Sozomena (HE II 4, 89), a nie do Euzebiusza, który będąc współczesny Konstantynowi, jako pierwszy zamieścił list cesarza. Autorka cytuje natomiast w przypisie fragment VC II 46 (w thumaczeniu A. Lisieckiego i podaje odniesienia do PG 20, 1021-1024, choć w bibliografii figuruje także edycja J.A. Heikela), a więc listu Konstantyna napisanego z innej okazji.

W rozdziale „Geneza chrześcijańskich Peregrinationes” Autorka wymienia główne przyczyny narodzi chrześcijańskiego pielgrzymowania: te, które określa jako ,ideologiczno-kultowe” oraz kult męczenników. Na s. 82 Autorka pisze, że nie sposób uniknąć pytań dotyczących teologii i duchowości tego okresu" oraz, że „uwidacznia się potrzeba wyjaśnienia samej koncepcji «świętego miejsca»". Niestety B. Pawłowska nie podejmuje tych kwestii. Nie ukazuje też, jak trudnym dla teologów IV wieku (zwłaszcza dla Euzebiusza z Cezarei) było wytłumaczenie nie tylko innym, lecz także sobie, że Bóg działa bardziej w pewnych, wybranych przez Niego miejscach, niż w pozostałych (co zresztą dobrze ukazuje książka P.W.L. Walkera - Holy City Holy places? Christian attitudes to Jerusalem and the Holy Land in the fourth century, Oxford 1990, na którą Autorka powołuje się kilkakrotnie); taki problem miał także Atanazy z Aleksandrii. Dyskusyjnym może też być uznanie, że „Powstanie nowego chrześcijańskiego imperium spowodowało, iż Kościół, aby odnaleźć swą własną tożsamość w nowej rzeczywistości, zaczął sam szukać swoich historycznych korzeni. Zainteresowanie Palestyną, jako ziemia związaną z życiem i działalnością Chrystusa, stało się więc naturalną potrzebą Kościoła. Eschatologiczna nadzieja prześladowanego Kościoła wyostrzyła świadomość historyczną oraz wyzwoliła pragnienie postrzegania Boga raczej w świecie doczesnym niż przyszłym" (s. 83) - dlaczego więc zjawisko pielgrzymowania chrześcijańskiego nie narodziło się w okresie „Małego pokoju Kościoła”? Odpowiedź (przynajmniej częściowa) zawarta jest w komentarzu Autorki do kwestii pojawienia się kultu relikwii: „w czwartym stuleciu znacznie wzrosła w chrześcijańskiej mentalności wiara w cuda i także samo pragnienie ich doświadczenia" (s. 84). Można powiedzieć, że doszło wtedy do pewnej przemiany postaw wobec otaczającej rzeczywistości - większą wagę przywiązywano nie tylko do cudów świętych, lecz także do wszelkich zjawisk nadprzyrodzonych (zagadnienie to obszernie przedstawił P. Janiszewski - Żywioły w stużbie propagandy, czyli po czyjej stronie stoi Bóg. Studium klęsk i rzadkich fenomenów przyrodniczych u historyków kościoła IV $i$ V wieku, w: Chrześcijaństwo u schytku starożytności, III, red. T. Derda - E. Wipszycka, Kraków 2000, 11-191).

W każdym razie kult męczenników i relikwii w 2. poł. IV wieku staje się faktem. W jego następstwie do grobów męczenników (i świętych w ogóle) 
przybywają pielgrzymi, często z odległych stron. B. Pawłowska, porównując kult chrześcijańskich świętych z kultem „boskich mężów” niechrześcijańskich, występującym w antyku, stwierdza za E. Wipszycką, że w przeciwieństwie do chrześcijańskich świętych „,moc antycznych «boskich mężów» [...] nie płynęła bynajmniej z ich grobów" (s. 85). Owszem kult męczenników opierał się przede wszystkim na kulcie relikwii, ale należy pamiętać, że zdarzały się wyjątki (np. św. Demetriusz, czynił cuda w w bazylice w Tesalonikach, choć nie było tam jego grobu). Warto też nie zapominać o tym, że kult relikwii, podobnie jak problem świętości miejsca, budził opór wśród niektórych hierarchów (np. spotkał się z krytyką wspomnianego Atanazego). Wreszcie należy poczynić jeszcze dwie uwagi: pierwsza dotyczy translacji relikwii Babylasa (do końca nie wiemy, czy odbyła się ona w 354 r., jak pisze B. Pawłowska; na pewno miała miejsce w latach 351-354, kiedy Antiochia była pod władzą Gallusa, por. Jean Chrysostome, Sur Babylas, SCh 362, 178-179), nie była ona translacją sensu stricto; szczątki Babylasa przeniesiono na odległość około $10 \mathrm{~km}$, z centrum Antiochii na jej przedmieścia - do Dafne. Pierwszą translacją „,z prawdziwego zdarzenia" była translacja relikwii Tymoteusza, Andrzeja i Łukasza do kościoła Apostołów (nie „Dwunastu Apostołów”, jak chce Autorka - s. 81) w 357 r. (najprawdopodobniej, choć nie wykluczone, odbyła się ona dwadzieścia lat wcześniej). Drugie uzupełnienie związane jest z celem pielgrzymek - oprócz grobów męczenników i miejsc świętych w Palestynie pielgrzymowano także do sanktuariów poświeconych Matce Boskiej lub poszczególnym aniołom.

Wymienione uproszczenia czy nieścisłości nie przesądzają jednak o wartości książki, o niej decyduje część druga, przygotowana znacznie rzetelniej. Autorka uwzględniła w niej bogatą literaturę przedmiotu (sięgając zarówno po klasyczne już, jak i najnowsze opracowania), odnoszącą się nie tylko do źródeł historycznych, lecz także archeologicznych. W przeciwieństwie do wprowadzających rozdziałów I-III, a przez to zawierających pewne uogólnienia, dalsze partie tekstu prezentują szczegółowe analizy. Część tę rozpoczyna krótki opis szlaków morskich i lądowych, prowadzących do Rzymu z różnych stron Imperium oraz krótka charakterystyka sposobów i warunków podróży (uwzględniająca także ceny i czas podróży). Można tutaj dodać dwie uwagi dotyczące podróży morskich: podróżowano często, w oględnie rzecz ujmując kiepskich warunkach - na statkach kobiety i mężczyźni nierzadko byli stłoczeni razem na pokładzie, znosząc wszystkie niedogodności podróży pod gołym niebem; z drugiej zaś strony istniała możliwość dostania się na statek nawet bez pieniędzy, odpracowywano wtedy przewóz w trakcie rejsu.

Następnie Autorka przechodzi do omówienia źródeł pisanych i (części źródeł epigraficznych). Czyni to dwuetapowo: najpierw prezentuje źródła, a potem opisane w nich miejsca kultu. Rozdział ten rozpoczyna charakterystyka Depositio Martyrum (i działalności papieża Damazego) i Martyrologium Hieronymianum. Ważnym elementem tej analizy są zamieszczone przykłady 
epigramów Dazmazego wraz z paralelnymi tłumaczeniami autorki. Cenne jest także tabelaryczne zestawienie dni, w których wspominano poszczególnych męczenników (wymienianych w Depositio Martyrum i Martyrologium Hieronymianum) oraz miejsc ich kultu. W dalszej części rozdziału B. Pawłowska charakteryzuje itineraria (poprzedza ja krótki opis Litania sempeforis oraz sakramentarzy: Sacramentarium Gelasianum i Sacramentrium Gregorianum) - Autorka uwzględnia wszystkie znane itineraria, których czas powstania odpowiada ramom chronologicznym książki: Notula de olea ss. Martyrum qui Romae in corpore requiescunt; Cymiteria totius Urbis Romae; De locis sanctis martyrum quae sunt forcis civitatis Romae; Itinerarium Malmesubriense). Pewne zastrzeżenia budzi jednoznaczne wiązanie Cymiteria.... (jest to bardzo lakoniczny wykaz 17 cmentarzysk rzymskich) z prezbiterem Janem, który jest autorem Notula de olea Martyrum (wykazu zawartości pittacia - etykiet od ampułek pielgrzymich, w które Jan zebrał olej z lamp płonących przy grobach męczenników, spoczywających na rzymskich cmentarzach). Zależność obu tekstów sugeruje V. Saxer (w opracowaniu cytowanym przez Autorkę), przy czym nie uzasadnia tego w żaden sposób (a wydawca obu tekstów nie odnotowuje ich wzajemnych powiązań - o konsekwencjach opowiedzenia się za jednym lub drugim rozwiązaniem będzie mowa później).

W drugiej części rozdziału V Autorka omawia cmentarze odwiedzane przez pielgrzymów (w kolejności zgodnej z De locis sanctis..., a więc przeciwnej, niż podana w Notitia Ecclesiarum). B. Pawłowska opisuje zatem miejsca kultu męczenników przy Via Cornelia, Via Aurelia Vetus, Via Portunese, Via Ostiensis, Via Ardeatina, Via Appia, Via Latina, Via Labicana, Via Tiburtina, Via Nomentiana, Via Salaria Nova, Via Salria Vetus i Via Flamina, zestawiając informacje zawarte w poszczególnych itinerariach, zwracając przy tym uwagę na róznice między tekstami (np. odmienne wersje zapisu imion tych samych męczenników, mogące wprowadzać czytelnika w błąd). W tekście omówione są jedynie wybrane cmentarze i bazyliki, którym towarzyszy charakterystyka niektórych świętych. Pełny wykaz czczonych świętych zamieszczony został w tabeli, wzorowanej jak się wydaje (choć nie podaje tego Autorka), na Tabula itinerariorum romanorum synoptica, zamieszczonej w CCL 176, 618-635, a uzupełnionej o dane z Depositio Martyrum i Martyrologium Hieronymianum (niestety główka tabeli na s. 198 nie została powtórzona na kolejnych ss. 199-214, na których znajduje się wykaz, przez co korzystanie z niego jest utrudnione). Lektura tabeli pozostawia pewien niedosyt. Otóż nie zostali w niej uwzględnieni święci Jan i Paweł, wymieniani w Notula de olea Martyrum. Tacy męczennicy byli czczeni na wzgórzu Coelio - wzmianki o nich znajdują się w Notitia Ecclesiarum i Itinerarum Malmesburiense (por. tabela s. 212 oraz tekst s. 190). Wydawca itinerariów rzymskich uznał, że imiona męczenników figurujące na pittacium (V) prezbitera Jana, powinny odnosić się w rzeczywistości do Piotra i Pawła, czczonych w katakumbach Sebastiana (CCL 175, 289), podobnie jak 
imię Agnes (figurujące na tej samej etykiecie) proponuje zastąpić imieniem Agapitus - wtedy wszystkie groby męczenników zlokalizowane byłyby w jednym rejonie - przy Via Appia, przez co sensowne byłoby umieszczenie ich obok siebie na jednej etykiecie. Z drugiej strony prezbiter Jan nie podaje miejsca, w których czczeni są owi męczennicy; można przypuszczać, że chodzi właśnie o wzgórze Coelio, jedyne miejsce, w którym wymieniani są razem Jan i Paweł. Coś zatem się nie zgadza, albo imiona, albo kolejność ich spisania (za tą drugą możliwością, w ogóle nie rozważając pierwszej, opowiedziała się ostatnio A. Karmańska - Trasa pielgrzymki Ojca Jana ad loca sancta w Rzymie, w: Sympozja Kazimierskie poświęcone kulturze świata późnego antyku $i$ wczesnego chrześcijaństwa, V, red. B. Iwaszkiewicz-Wronikowska - D. Próchniak, Lublin 2005, 237-256) - szkoda, że Autorka nie podjęła tego problemu.

Podczas lektury itinerariów rodzi się pytanie czy zawsze pielgrzymi okrążali Rzym (jak wynikałoby to z treści Notitia Ecclesiarum i De locis sanctis), czy też pielgrzymki odbywały się etapami, np. z centrum Rzymu udawano się na południowe przedmieścia Rzymu, następnego dnia na północne itd. Autorka nie porusza niestety tej kwestii. A Karmańska, która zaproponowała ostatnio we wspomnianym wyżej artykule uporządkowanie kolejności pittacia, łącząc odwiedzane miejsca przez Jana w kilka stref geograficznych. To mogłoby oznaczać, że Jan przebywał dłużej w Rzymie i odbywał swą pielgrzymkę krótkimi odcinkami, powracając do centrum miasta. Kluczowe dla rozwiązania tego problemu jest ustalenie ewentualnych powiązań Cimiteria totius Romanae Urbis z Notula de olea Martyrum (czego A. Karmańska nie bierze pod uwagę). Jeśli rzeczywiście Cimiteria zawiera wykaz miejsc odwiedzonych przez Jana (jak chce V. Saxer), wtedy miejsca opisane w Notula i Cimiteria tworzą trasę podobną do tych prezentowanych w Notitia Ecclesiarum i De locis sanctis. Jeśli uznamy, że Notula i Cimiteria nie łączy osoba prezbitera Jana, wtedy otrzymamy pośredni dowód na alternatywny sposób odbywania pielgrzymki po cmentarzach rzymskich. Zarówno w Cimiteria, jak i w Notula wymienione są niektóre miejsca z opisanych w Notitia i De locis sanctis, a więc oba teksty nie przedstawiają trasy okrążającej miasto.

Następny rozdział - VI, poświecony jest w dużej mierze rzymskim ksenodochiom. Tekst oparty został przede wszystkim na artykule S. Longosza, Ksenodochium - hospicjum wczesnochrześcijańskie (VoxP 16:1996, t. 30-31, 275336). Autorka niewielkie ustępy przytacza dosłownie (bez zaznaczania cytatów), parafrazuje fragmenty tego opracowana, (por. np. s. 218 u Pawłowskiej i 278 u Longosza, odpowiednio s. 233 i 321; 238 i 328; s. 223 i 333), a powołuje się na nie jedynie w dwóch miejscach. Na podstawie artykułu S. Longosza B. Pawłowska omawia organizację ksenodochiów, przedstawia pokrótce rzymskie ksenodochia, ich lokalizację oraz funkcjonowanie, odtwarza wygląd ksenodochium Pammachiusza, a wreszcie wspomina klasztory (zamieszcza także ich wykaz tabelaryczny), w których zatrzymywali się pielgrzymi zmierzający do 
Rzymu. W oparciu o regułę św. Benedykta (zamieszczono fragmenty w thumaczeniu Autorki) przedstawiono, jak w praktyce wyglądał pobyt pielgrzymów w ksenodochium (a raczej, jak powinno przebiegać przyjmowanie podróżnych). Ostatnia część tego rozdziału, zatytułowana jest „Pobyt ad loca sancta". Autorka omawia w niej organizację uroczystości oraz przebieg liturgii w różnych miejscach kultu męczenników (przede wszystkim na podstawie Peristephanon Prudencjusza), wymienia także dewocjonalia zabierane przez pielgrzymów z Rzymu.

Rozdział ten także wymaga krótkiego komentarza. Na s. 217 Autorka pisze, że „przybywający [do Rzymu] ludzie [pielgrzymi] musieli znajdować gdzieś nocleg i doraźną opiekę. Nie mogły być to przecież zwykłe tawerny, o których przecież wiadomo było, że uchodzą za nieodpowiednie miejsce dla chrześcijanina, a zwłaszcza pątnika. Zresztą synod w Laodycei z 375 r. wydał zakaz korzystania $z$ usług prywatnych tawern". Nie można jednak zapominać, że pierwsi pielgrzymi pojawiają się w Rzymie już w 1. poł. IV wieku, kiedy nie istnieją jeszcze ksenodochia. Trzeba mieć również na uwadze realia podróży czasów późnej starożytności, np. pielgrzym z Bordeaux (por. s. 278) wymienia dziewięć mansiones (zajazdów, gospód) i czternaście mutationes (punktów zmiany koni) na trasie z Kapui do Rzymu (136 mil), a z Rzymu do Ariminium (224 mile) dwadzieścia trzy mutationes i czternaście mansiones (CCL 175, 24-25). Owszem, w takich „centrach pielgrzymkowych”, jakim np. był Rzym, pielgrzymi mogli korzystać przede wszystkim z ksenodochiów, natomiast niewątpliwe po drodze zatrzymywali się w zwykłych mansiones (choć nie wiemy, jak często). Opisy osób, które odwiedzały tego typu miejsca, a także zachowane grafitti, wydrapane przez nocujących w mansiones, dają obraz, najogólniej określając, kwater kiepsko wyposażonych, nierzadko o marnej reputacji; a także wystawiają czasem niepochlebne świadectwo o kulturze osobistej gości (i choć nie zawsze musiało tak być, jak pisze Grzegorz z Nyssy, w liście cytowanym przez autorkę - s. 217 - że w zajazdach i gospodach „brudzi się serce, przyjmując przez wzrok i słuch bezeceństwa”, to jednak atmosfera zajazdów w niczym nie przypominała pobożności dzisiejszych pielgrzymek).

Ostatni rozdział „Peregrini w Rzymie” podzielony jest na dwie nieproporcjonalne części. W pierwszej, znacznie obszerniejszej, wymienione są osoby, które przybywały z pielgrzymką (podróżą) do Rzymu w okresie IV-VII wieku, a które są wspomniane w źródłach pochodzących z tego czasu. Autorka analizuje teksty źródłowe w porządku chronologicznym (a wiec odnoszące się do czasów przedkonstanyńskich i pokonstanyńskich - z IV, V, VI i VII wieku). Wiele miejsca w tym rozdziale poświęcono problemowi powstania i rozwoju prymatu biskupa Rzymu. Wreszcie B. Pawłowska omawia pokrótce grafitii z katakumb (słusznie zauważając, że „epigrafika katakumbowa nie może być w żadnym przypadku podstawą do szczegółowych analiz statystycznych", s. 303), zamieszczając przy tym teksty inskrypcji. 
Całe opracowanie zamyka „Zakończenie” (ss. 317-322) będące z jednej strony podsumowaniem całości, z drugiej bardziej osobistą refleksją autorki. Cennym uzupełnieniem publikacji są tablice chronologiczne i ilustracje (mapy, plany zdjęcia - niestety tylko przy wybranych podano źródło, z którego zostały zaczerpnięte) zamieszczone na końcu książki (trzeba przyznać wydawcy, że nawet czarno-białe ryciny zostały wydrukowane na papierze kredowym). Tablice ułatwiające czytelnikowi porządkowanie podczas lektury informacji zawartych w książce, niewątpliwie mogą okazać się dla niego pomocne. Zawierają trzy rubryki: wydarzenia polityczne, historia powszechna religii, peregrynacje. Rubryka historia powszechna religii, nazwana jest na wyrost, bo oprócz kilku dat z historii islamu, dotyczy wyłącznie chrześcijaństwa (brak w niej np. ważnych wydarzeń dla pogańskich kultów rzymskich, stanowiących pewne umowne cezury, takich jak usunięcie ołtarza Wiktorii z senatu czy zrzeczenie się przez Gracjana tytułu pontifex maximus, lub zniszczenie Serapejonu w Aleksandrii, albo informacji o ostatnich igrzyskach olimpijskich), a wybór dat z historii chrześcijaństwa jest subiektywny, np. nie uwzględniono soboru w Konstantynoplu w 381 roku.

Autorka zaznacza we wstępie, że opracowania graficzne „stanowią substancjonalną część pracy” (s. 24); rzeczywiście B. Pawłowska powiązała ilustracje z tekstem. Materiał graficzny, bezsprzecznie wzbogacający książkę, niestety nie jest wolny od pewnych mankamentów; planom architektonicznym brak skal informujących o rozmiarach budowli. Zastrzeżenia może budzić też dobór niektórych ilustracji, np. powtarzane podobne ujęcia niektórych obiektów lub też wybór planu przedstawiającego bazylikę Grobu Bożego w Jerozolimie skoro opracowanie dotyczy okresu IV-VII wieku, lepiej by było, gdyby plan ukazujący współczesną sytuację, zastąpić planem bazyliki konstantyńskiej, albo gdyby przynajmniej uwzględniono w opisie, jaką fazę budowy obiektu plan obrazuje.

Na koniec jeszcze kilka uwag o stronie technicznej książki, odnoszących się już raczej nie do Autora, ale Wydawcy. Czemu nieliczne przypisy oznaczone są jako przypisy autora, czyżby pozostałe (większość przypisów) pochodziły od redaktora? Podczas lektury opracowania trudno nie zauważyć pewnych lapsusów językowych (widocznych już we wstępie); niektóre cytaty łacińskie sprawiają wrażenie, jakby w ogóle nie zostały poddane korekcie; na nienajlepszą jakość korekty technicznej wskazują też takie potknięcia, jak nieprawidłowy zapis imienia teściowej Konstantyna (Eutopia), dwukrotne uwzględnienie publikacji Drijversa w bibliografii, błędy w zapisie bibliograficznym, czy też przypisanie J. Naumowiczowi autorstwa książki La navigazione mediterranea nell'Alto Medievo; i inne tego typu niedociągnięcia, które pojawiają się na tyle często, że świadczą o niestarannym zredagowaniu książki. Pozornie są to sprawy błahe, jednak nawet te szczegółowe kwestie mogą być uciążliwe dla czytelnika, który sięgając po książkę tak poważnego wydawnictwa, jakim jest WAM, 
oczekuje, że publikacja będzie prezentować nie tylko wysoki poziom merytoryczny, lecz także zostanie sumiennie zredagowana.

Podsumowując, należy stwierdzić, że mimo pewnych niedoskonałości publikacja B. Pawłowskiej, jest rzeczowym opracowaniem, z jednej strony podsumowującym ogólny stan badań na temat pielgrzymek późnoantycznych, z drugiej zaś zawierającym cenną analizę źródeł informujących o peregrinationes do Rzymu między IV a VII wiekiem. Co prawda, książka pozostawia pewien niedosyt, ale dzięki temu może ona stać się asumptem do dalszych badań nad tą problematyką, nie tylko dla Autorki.

Paweł Wróblewski - Warszawa, UKSW

\begin{abstract}
Beata PAWŁOWSKA, Urbs Sacra. Pielgrzymki i podróże religijne do Rzymu w starożytności chrześcijańskiej (IV-VII wiek), Wydawnictwo WAM, Kraków 2007, ss. 372 + XLVIII.
\end{abstract}

W bogatym świecie duchowości religijnej niewiele jest takich form pobożności, które pomimo upływu czasu oraz istotnych zmian w ludzkiej mentalności niezmiennie przyciągają wiernych, dając im możliwość uzewnętrznienia tych samych duchowych potrzeb i doświadczenia podobnych przeżyć, które towarzyszą ludziom żyjącym w każdej epoce i wyznającym niemal każdą znaną nam religię. Fenomenem takim z pewnością są pielgrzymki. Oczywiście, w poszczególnych religiach i epokach historycznych cieszą się one rozmaitą popularnością. Nawet w chrześcijaństwie - religii, z którą w naszym kręgu kulturowym najczęściej wiążemy peregrynacje - bywały okresy, gdy stanowiły one zjawisko marginalne. Nigdy jednak nie zanikły one całkowicie, a dziś możemy obserwować ich ponowny rozkwit.

Zainteresowanie pielgrzymkami nie dotyczy wyłącznie bardziej wrażliwych wiernych. Fenomen ten zastanawia również naukowców i prowadzi ich do nader interesujących badań. Ostatnie półwiecze zaowocowało na tym polu znaczną liczbą opracowań. Szczególne miejsce wśród nich zajmują prace historiograficzne, wychodzące spod piór mediewistów oraz badaczy starożytności chrześcijańskiej. Analizując najstarsze świadectwa historyczne pytają oni, m.in. o genezę samego zjawiska, jego charakter, kierujące pielgrzymami motywy, najczęściej odwiedzane miejsca, a także o organizację dawnych peregrinationes. Ze zrozumiałych względów najwięcej uwagi w tego typu pracach poświęcane jest Ziemi Świętej. Drugie, niezwykle ważne dla chrześcijan miejsce, jakim jest Rzym, cieszyło się w tej mierze znacznie mniejszym zainteresowaniem. Na temat pielgrzymek i podróży religijnych do Wiecznego Miasta powstała wprawdzie pewna liczba przyczynkowych studiów, ale do tej pory brakowało jednak pracy o charakterze bardziej kompleksowym, zawierającej zarówno wnikliwe 